\title{
The blame game
}

Two articles hit my screen this week, one from the website Medical Express $^{[1]}$ and the second from the Guardian Online. ${ }^{[2]}$ Both are essentially about the same thing - how the food industry is behaving exactly like the tobacco industry and preventing people from understanding the harms of excess sugar intake. The bottom line is that the food industry has climbed onto the dietary guidelines bandwagon and obfuscated the science that has for decades been suggesting that a high intake of sugar is harmful.

In 2007, Cristin Kearns, a postdoctoral fellow at the University of California School of Medicine, heard a speaker at a dental conference endorse a sugar-laden tea. When challenged, he replied that there is no evidence linking sugar to chronic disease. Another speaker shared a dietary pamphlet from the US National Diabetes Education Program, which said nothing about sugar intake. Kearns' journey began, during which she found that the US Sugar Association had led the way in the sugar industry's decades-long strategy to downplay the potentially harmful role of sweeteners on health. In studies published in peer-reviewed journals, she showed that the Sugar Association recognised as long ago as 1954 that if Americans adopted a low-fat diet, their per capita consumption of sugar would increase by onethird. When, during the 1960s, researchers started to look at the relationship between sugar consumption and heart disease, industrysponsored studies promoted fat as the culprit. Kearns also found that the industry withheld vital evidence. When a 1968 study looking at the connection between sugar and heart health found conclusive evidence that sucrose raises blood triglycerides by interacting with gut bacteria, the foundation ended the study. The same study showed a possible link between sucrose and bladder cancer.

Dean Schiller, a diabetes specialist, also probed biases in sugar science, and in a report in the Annals of Internal Medicine, co-authored with Kearns, reviewed 60 studies between 2001 and 2016 that looked at the role of sugary drinks in diabetes and obesity. Of the 26 studies that found no link, all were funded by the sugar-sweetened beverage industry or conducted by people with financial ties to the industry. Of the 34 studies that found a link, only one was industry funded.

And then we have the British Medical Journal article by Susan Greenhalgh, ${ }^{[3]}$ a research professor of Chinese society. US targeting of the soft-drink industry is starting to work and, like tobacco, as their market in the West shrinks, the industry is targeting the global South. China is now Coke's third largest market by volume, and as Coke and other Western food manufacturers have entered this market, so China's rates of obesity have risen. But Coke's success, according to Greenhalgh, is due to more than good marketing. Coke has been leveraging the Chinese branch of an organisation created 40 years ago to advance its interests around the world, the International Life Sciences Institute, which is housed within the Chinese Centre for Disease Control and Prevention, a unit of the government health industry. Through this relationship and a 'complex web of institutional, financial, and personal links, Coke has been able to influence China's health policies'.

And so we come to the blame game. Because sugar-linked chronic diseases are preventable by changes in diet and physical activity, people who are obese are accused of making bad choices and being lazy. Sugary drink companies even claim that their products add to a healthy lifestyle. But the dramatic spike in the so-called diseases of lifestyle that has happened over the past four decades is not due to changes in people's behaviour. It is due to a change in the environment. All you have to do is check the ingredients list in packaged foods and look at the added sugars - in yogurt, cereal, salad dressing, soups, breads, cold meats, pasta sauces - the lists go on. Unless you buy everything completely fresh and prepare all your meals from scratch, you are going to be consuming huge quantities of added sugars, and that is not even starting to count the sugars you know you are consuming when you eat sweets and desserts. The changes need to come from industry and government policy, and they need to come now. Even children are suffering from the effects of this toxic environment, with fatty livers and even type 2 diabetes at a young age. It is up to those of us who have influence in health policy to start looking at the evidence objectively and do what was done with tobacco (in the Western world at least) - stop it in its tracks.

Bridget Farham

Editor

ugqirha@iafrica.com

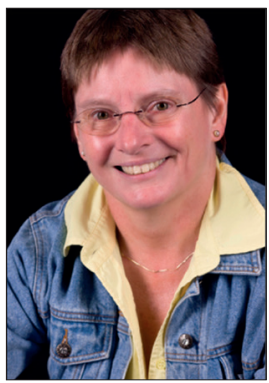

1. Sugar's sick secrets: How industry forces have manipulated science to downplay harm. https:// medicalxpress.com/news/2019-01-sugar-sick-secrets-industry-science.html?fbclid=IwAR3e7p5JXQ2 GIZ5Fx8hJoXDDhHUvXSx0gHl-xuQx-bl_yXcaYcMcFTQ--M0 (accessed 16 January 2019).

2. Coca-Cola influences Chinass obesity policy, BMJ report says. https://www.theguardian.com/ business/2019/jan/10/coca-cola-influence-china-obesity-policy-protect-sales-bmj-report (accessed 16 January 2019).

3. Greenhalgh S. Making China safe for Coke: How Coca-Cola shaped obesity science and policy in China. BMJ 2019;364:k5050. https://doi.org/10.1136/bmj.k5050

S Afr Med J 2019;109(2):64. DOI:10.7196/SAMJ.2019.v109i2.13909 